\title{
PENINGKATAN KOMPETENSI PENGAJAR BAHASAARAB DI PONDOK PESANTREN DARUSSALAM, NARUNGGUL TANJUNGPURA, RAJAPOLAH KABUPATEN TASIKMALAYA JAWA BARAT
}

\author{
Nurina Dyah Putrisari, dan Eka Kurnia Firmansyah \\ Fakultas Ilmu Budaya Universitas Padjadjaran \\ E-mail: nurina.dyah@unpad.ac.id
}

\begin{abstract}
ABSTRAK. Kegiatan Pengabdian kepada Masyarakat yang dilakukan oleh tim pengabdian dilatarbelakangi oleh minimnya pelatihan bagi para pengajar dan calon pengajar bahasa Arab PP Darussalam yang berbasis dinamika faktual pengajaran bahasa Arab di Indonesia. Selama ini, para guru dan kandidat guru bahasa Arab belajar, mengajar, dan melaksanakan micro teaching di lingkungan berbahasa yang sangat kondusif, sedangkan potret faktual pembelajaran bahasa Arab di lingkungan masyarakat begitu sarat tantangan, seperti lingkungan berbahasa yang tidak kondusif, rendahnya minat dan motivasi peserta didik, serta alokasi waktu yang sangat terbatas bagi pembelajaran bahasa Arab. Maka pelatihan dalam PPM ini bertujuan untuk meningkatan kompetensi pengajar dan calon pengajar bahasa Arab di PP Darussalam dengan materi yang mencakup kompetensi pedagogik dan akademik guru, ditambah strategi pengajaran bahasa Arab sebagai bahasa Asing di lingkungan non Pesantren. Dalam kegiatan ini digunakan metode kualitatif yang meliputi wawancara mendalam dan observasi partisipasi. Di dalam pelaksanaannya, dilakukan melalui serangkaian kegiatan yang meliputi: klasifikasi, penataran, pendampingan, dan kaji tindak. Setiap survei menghasilkan rencana dan evaluasi program yang akhirnya menghasilkan 3 program utama PPM ini, yaitu: (1) Penyusunan Karya Pengabdian berupa Modul "ta'zizu kafaati mu'allimil lughah al-'arabiyyah li'n nathiqina bighairiha" atau Penguatan Kompetensi Pengajar Bahasa Arab bagi Penutur Non-Arab", (2) Program Pelatihan bagi Kandidat Pengajar Bahasa Arab di Pesantren Darussalam, (3) Program Arabic Camp sebagai pelatihan untuk meningkatkan kapasitas kandidat pengajar bahasa Arab. Hingga berakhirnya PPM di Bulan November, pelaksanaan program ini berjalan lancar dan mendapat apresiasi dari sasaran program. Luaran yang dihasilkan dari kegiatan ini adalah karya pengabdian berupa modul pelatihan dan artikel jurnal.
\end{abstract}

Kata kunci: pengajaran bahasa Arab; pengajar bahasa Arab; pesantren modern

ABSTRACT. The program was held based on lack of training for Arabic teachers and its candidates in Pesantren Darussalam in scope of the factual dynamics of teaching Arabic in Indonesia. So far, teachers and candidates for Arabic language teachers have learned, taught, and implemented micro teaching in a very conducive language environment, while factual portraits of Arabic learning in the community are so full of challenges, such as a non-conducive language environment, low interest and motivation of students, and very limited time allocation for learning Arabic. Then the training aims to improve the competence of Arabic teachers and its candidates in Pesantren Darussalam with material that includes teacher pedagogical and academic competencies, added with strategies for teaching Arabic as a foreign language in non-Islamic boarding schools. In this activity qualitative methods are used which include in-depth interviews and participation observations. In its implementation, it is carried out through a series of activities which include: classification, upgrading, mentoring, and action review. Each survey produced a program plan and evaluation which eventually resulted in 3 main programs, namely: (1) Designing modules "ta'zizu kafaati mu'allimil lughah al-'arabiyyah li'n nathiqina bighairiha" or Strengthening Language Teacher Competence Arabic for Non-Arabic Speakers “, (2) Training Program for the candidates of Arabic teachers, (3) Arabic Camp Program as a training to increase the capacity of Arabic teaching candidates. Until the end of the PPM in November, the implementation of this program went well and received appreciation from the program targets. The output generated from this activity is Arabic training modules and journal articles.

Key words: Arabic learning; Arabic teachers; modern Islamic boarding school

\section{PENDAHULUAN}

Lingkungan bahasa memiliki peran penting dalam proses pembelajaran bahasa, terutama bahasa asing. Lingkungan berbahasa adalah lingkungan yang diatur sedemikian rupa agar para pembelajar bahasa dapat mencapai tujuan pembelajaran melalui proses pemerolehan bahasa (iktisabu 'llughah) dengan porsi yang lebih banyak dari pada pengajaran bahasa itu sendiri (ta'limu 'llughah). Lingkungan bahasa dapat dibentuk dengan mewajibkan para pembelajar untuk terus konsiten aktif berbahasa asing, dan menjadikan segala unsur yang didengar, dilihat dan dibaca menggunakan bahasa asing yang menjadi bahasa target.

Dalam sejarah dan dinamika pembelajaran bahasa Arab di Indonesia, lingkungan seperti ini telah banyak terbentuk di berbagai pondok pesantren modern di Indo- nesia, tidak terkecuali Pondok Pesantren Darussalam Narunggul, Rajapolah, Tasikmalaya. Dalam keseharian santri dan guru, mereka telah terbiasa menggunakan bahasa Arab sebagai bahasa yang digunakan sehari-hari dengan didukung lingkungan berbahasa yang kondusif. Maka bahasa Arab di Pesantren ini telah menjadi bahasa kedua, bukan lagi bahasa asing, begitu pula dengan model pembelajarannya.

Suasana dan kondisi positif seperti ini ternyata memiliki sisi lain bagi para pembelajarnya yang juga merupakan para kandidat guru bahasa Arab. Para pembelajar yang setiap saat terbiasa dengan lingkungan berbahasa yang kondusif akan membutuhkan sedikit penyesuaian saat harus mengajar di lembaga-lembaga yang tidak terbentuk lingkungan berbahasa di dalamnya. Potret pengajaran bahasa Arab di banyak lembaga nonpesantren, seperti telah banyak diketahui, memiliki banyak 
tantangan bagi para pengajarnya. Tantangan tersebut bisa datang dari banyak sumber, seperti lingkungan berbahasa yang tidak kondusif, rendahnya minat dan motivasi peserta didik untuk belajar bahasa Arab, serta alokasi waktu yang sangat terbatas bagi pembelajaran bahasa Arab.

Tantangan pengajaran bahasa asing seperti yang telah disebutkan di atas membutuhkan pengetahuan, keterampilan, dan strategi yang tepat dari para pengajarnya, karena tujuan pengajaran bahasa Arab di luar Pesantren sangatlah heterogen. Maka atas dasar inilah Tim Pengabdian pada Masyarakat Prodi Sastra Arab FIB Unpad mencetuskan gagasan untuk memberikan pelatihan peningkatan kompetensi pengajar bahasa Arab dan para kandidatnya.

Selama ini para calon pengajar di Pesantren Darusslam juga mendapatkan pelatihan dan pembekalan sebelum kelulusan dan mengabdi sebagai pengajar yang ditugaskan di berbagai tempat, namun pelatihan tersebut masih terbatas pada penyampaian metode dan strategi mengajar yang selama ini berjalan di lingkungan pondok pesantren serta sedikit mengesampingkan kondisi faktual dan pengalaman mengajar di luar lingkungan pesantren. Hal ini disebabkan belum adanya SDM yang dapat menyampaikan materi tersebut karena para pelatih dari tahun ke tahun hanya didatangkan dari pengajar setempat yang belum banyak memiliki pengalaman seperti kualifikasi yang telah diuraikan sebelumnya.

Program pelatihan yang dirancang bagi Pondok Pesantren Darussalam adalah pelatihan berbasis pengalaman dan dinamika faktual pengajaran bahasa Arab di lingkungan non-Pesantren. Konten materinya mencakup kompetensi pedagogik dan akademik guru, ditambah strategi pengajaran bahasa Arab sebagai bahasa Asing di lembaga-lembaga non Pesantren. Secara lebih spesifik, metode-metode pengajaran yang dikenalkan dalam pelatihan ini adalah metode-metode selain metode langsung (direct method) yang selama ini digunakan di Pesantren Darussalam. Di antara metode-metode tersebut adalah metode gramatika-terjemah, metode audio-lingual, metode membaca, metode komunikatif serta metode pengajaran bahasa yang diadopsi dari metode pengajaran modern seperti silent way dan suggestopedia. Program pelatihan seperti ini bertujuan agar para pengajar dan calon pengajar bahasa Arab menjadi lebih terampil dan dapat menyesuaikan metode, pendekatan, dan strategi pengajaran bahasa sesuai tujuan pembelajaran bahasa dan kondisi peserta didik, materi, serta alokasi waktu yang tersedia bagi pengajaran bahasa tersebut.

\section{METODE}

Jenis metode yang digunakan dalam pengabdian ini adalah metode kualitatif yang meliputi wawancara mendalam dan observasi partisipasi. Di dalam pelaksanaannya dilakukan serangkaian kegiatan yang meliputi: klasifikasi, penyuluhan, pendampingan, dan kaji tindak.
Sedangkan model metode yang digunakan adalah model pendidikan masyarakat yang meliputi: a) continuing education dengan pendampingan dan kaji tindak dalam bentuk pelatihan bagi calon pengajar di Pesantren Darussalam. Pelatihan ini dianggap penting untuk memberikan bekal pengetahuan bagi para pengajar bahasa Arab bagi penutur non-Arab agar dapat mengajar dengan metode dan strategi yang tepat. Selain itu, model metode ini diterapkan dalam program Arabic Camp untuk meningkatkan kapasitas berbahasa Arab calon pengajar. Pelatihan ini mencakup pengajaran bahasa Arab komunikatif serta pembahasan dari segi fonologis, kosa kata, dan gramatika; b) penyuluhan dilakukan untuk menyampaikan strategi pengajaran bahasa Arab bagi penutur non Arab dengan berbagai penyesuaian dengan tujuan, materi, alokasi waktu, kelompok belajar dan unsur-unsur lainnya. Penyuluhan ini disampaikan dengan pendekatan kelompok disertai teknik komunikasi informatif dan persuasif.

Pesantren Darussalam Rajapolah Tasikmalaya dipilih menjadi lokasi pengabdian karena pesantren ini menerapkan sistem kulliyyatul-mu'allimin as-islamiyyah atau Sekolah Pendidikan Guru Islam sehingga setiap tahunnya mengadakan pelatihan mengajar bagi siswa dan siswi kelas VI (setara dengan kelas XII SMA) yang akan menjadi pengajar dalam masa pengabdian selama 1 tahun. Namun selama ini dalam pelatihan yang berlangsung, materi tentang metode pengajaran bahasa yang disampaikan masih terbatas pada metode langsung. Berdasarkan kondisi tersebut, tim PPM berinisiatif untuk menyampaikan variasi metode lainnya dalam pengajaran bahasa asing seperti metode gramatika-terjemah, metode audio-lingual, metode membaca, metode eklektik dan metode lainnya sehingga para calon pengajar dapat menyesuaikan penggunaannya dengan tujuan pembelajaran bahasa asing di tempat mengabdi.

Pihak-pihak yang terlibat dalam proses penyampaian materi pada kegiatan pengabdian ini adalah Pimpinan dan Divisi Kurikulum Pesantren sebagai pengarah dan nara sumber kegiatan, serta guru-guru senior Pesantren yang setiap tahunnya rutin menjadi nara sumber pelatihan. Pada kegiatan pengabdian saat ini, guru-guru pesantren menyampaikan materi tentang metode langsung, sedangkan Dosen Pelaksana PPM menyampaikan variasi metode pengajaran bahasa Arab bagi penutur non-Arab.

\section{HASIL DAN BAHASAN}

Hasil Identifikasi Awal Pembelajaran Bahasa Arab di Pondok Pesantren Darussalam Rajapolah Tasikmalaya serta Metode Pengajarannya

Pembelajaran bahasa Arab di Pesantren Darussalam Rajapolah Tasikmalaya disampaikan dengan menggunakan metode langsung atau direct method. Dalam metode langsung, guru mengajar bahasa asing yang menjadi bahasa target tanpa menggunakan bahasa ibu sebagai bahasa 
pengantar. Dengan metode ini, guru juga menghindari penerjemahan bahasa target ke dalam bahasa ibu sebisa mungkin. Beberapa cara yang dapat digunakan untuk menyampaikan pengajaran bahasa dengan metode ini di antaranya dengan menunjuk objek dengan pelafalan kosa kata dalam bahasa target, mempraktikkan sebuah ekspresi atau kata kerja, membuat kalimat dengan kosa kata yang akan disampaikan sehingga maknanya dapat diterima dan dipahami oleh pembelajar, asosiasi kata, menyebutkan sinonim atau antonimnya, dan dalam pilihan terakhir, pengajar diperbolehkan menerjemahkan makna yang dimaksud ke dalam bahasa ibu dalam kondisi pembelajar tidak dapat memahami makna yang disampaikan dengan cara-cara di atas. Meskipun diperbolehkan, penerjemahan ke dalam bahasa ibu merupakan sesuatu yang harus dielakkan dalam pengajaran bahasa asing dengan metode ini.

Pengajaran bahasa Arab bagi penutur non-Arab dengan metode langsung bertujuan untuk menyampaikan makna bahasa asing/bahasa target kepada pembelajar tanpa bahasa ibu sebagai perantara dalam pemaknaan suatu kata, frasa atau klausa. Metode yang digunakan di mayoritas pesantren modern di Indonesia ini membentuk sebuah lingkungan bahasa yang kondusif. Karena metode langsung akan sulit diterapkan tanpa adanya dukungan dari lingkungan berbahasa yang sedemikian rupa dibentuk agar segala sesuatu yang didengar, dilihat dan diucapkan pembelajar bahasa adalah bahasa asing yang ditargetkan. Kondisi seperti ini pula yang ditemukan Tim PPM dari hasil identifiksi awal di lingkungan sasaran. Pesantren ini mewajibkan seluruh santri dan guru untuk bercakapcakap dalam bahasa Arab dan Inggris secara bergiliran setiap 2 pekan. Maka seluruh percakapan yang terdengar di Pesantren ini adalah percakapan dalam bahasa Arab dan Inggris. Semua bentuk pengumuman dan surat edaran disampaikan dalam bahasa Arab dan Inggris sesuai pekan wajib bahasa yang berlaku. Dari hasil wawancara dengan salah satu pengajar, hal ini deterapkan untuk membentuk sebuah laboraturium bahasa di kawasan Pesantren, karena pembelajaran bahasa asing pada umumnya hanya menekankan pembelajaran di dalam kelas tanpa praktik langsung.

Selain itu, dalam proses pembelajaran formal di dalam kelas, metode pengajaran yang digunakan oleh para guru adalah metode langsung. Sebagai contoh pada masa observasi, dalam mata pelajaran muthala'ah yang bertujuan agar siswa mampu menguasai wacana dalam bahasa Arab, maka guru akan mengajar satu judul wacana dalam dua pertemuan. Pada pertemuan pertama guru hanya mengajarkan seluruh kosa kata baru dan kosa kata yang dianggap sulit oleh siswa. Kosa kata disampaikan dengan metode langsung sehingga menghabiskan satu pertemuan karena guru benar-benar menghindari penerjemahan ke dalam bahasa ibu. Selanjutnya dalam pertemuan kedua guru menyampaikan penjelasan isi wacana dari teks yang telah dipelajari seluruh kosa katanya. Hal ini memang memakan waktu yang relatif lama namun memberikan hasil yang cukup signifikan karena siswa dengan mudah mengingat kosa kata dan menyampaikan kembali isi wacana yang disampaikan.

\section{Sasaran Program Pengabdian}

Sasaran program dalam pengabdian ini adalah siswa dan siswi tingkat akhir Pesantren Darussalam Tasikmalaya. Para sasaran program memiliki kewajiban untuk menjalani serangkaian kegiatan sebagai syarat kelulusan, di antaranya adalah micro teaching atau praktik mengajar dan evaluasi kelompok dengan metode peer review. Praktik mengajar bertujuan untuk mempersiapkan para lulusan Pesantren untuk melaksanakan pengabdian wajib setelah kelulusan selama satu tahun. Program paraktik mengajar juga merupakan manifestasi dari salah satu sistem Pesantren yaitu "kulliyyatu al-mu'allimin alislamiyyah" atau Sekolah Pendidikan Guru Islam. Hampir semua Pesantren Modern yang merupakan cabang atau rintisan alumni Pondok Modern Gontor menganut sistem ini.

Meskipun program tersebut telah berjalan dengan baik selama Pesantren berdiri, namun terdapat catatan dari para alumni yang telah mengajar dan menjadi bahan evaluasi bagi keberlangsungan program. Evaluasi tersebut adalah perlunya pembekalan metode mengajar yang variatif serta gambaran fenomena pengajaran bahasa Arab di luar pesantren. Hal ini disebabkan karena lingkungan kebahasaan tempat para siswa akhir melangsungkan praktik mengajar sudah terbentuk sedemikian rupa dan hanya menuntut para calon alumni untuk melaksanakan praktik mengajar dengan metode langsung. Sedangkan kondisi faktual pengajaran bahasa Arab di sekolah-sekolah pada umumnya bisa sangat berbeda dengan lingkungan yang kondusif dalam Pesantren. Dan untuk menghadapi kondisi di luar pesantren tersebut diperlukan wawasan yang lebih luas tentang metode dan strategi pengajaran yang tepat sesuai dengan tujuan, kurikulum, kondisi guru dan siswa, bahan ajar, serta unsur pendukung lainnya.

\section{Penyusunan Modul Pelatihan}

Tahapan kedua setelah identifikasi lapangan adalah penyusunan modul yang akan digunakan dalam pelatihan. Modul ini berjudul "ta'zizu kafaati mu'allimil lughah al-'arabiyyah li al-nathiqin bighairiha" (Penguatan Kompetensi Pengajar Bahasa Arab bagi Penutur NonArab). Modul ini memuat dasar-dasar pengetahuan yang harus dimiliki seorang pengajar bahasa Arab baik dari ranah pedagogisnya hingga pengetahuan yang secara khusus berkaitan langsung dengan pengajaran bahasa asing, khususnya bahasa Arab. Modul ini disusun oleh Tim PPM yaitu Elnazier Mohammed Ahmed Elbadi sebagai penulis utama serta Eka Kurnia, Nurina Dyah dan Yani Rohmayani sebagai penulis pendamping. Tim penulis modul adalah dosen yang kompeten dan sudah menghasilkan beberapa tulisan di bidang pengajaran bahasa Arab bagi penutur non-Arab. 
Modul ini terdiri dari 11 judul dengan uraian sebagai berikut: 1) Wawasan Pedagogis bagi Pengajar; 2) Metode-metode Pengajaran Bahasa Asing; 3) Analisis Kontrastif dan Kesilapan Bahasa; 4) Tes Bahasa; 5) Pengajaran Bahasa Arab; 6) Pengajaran Unsur-unsur Bahasa; 7) Pengajaran Keterampilan-keterampilan Bahasa; 8) Pengajaran Bahasa Arab untuk Pemula; 9) Permainan-permainan Bahasa; 10) Latihan-latihan Kebahasaan; 11) Problematika Pengajaran Bahasa Arab untuk Penutur non-Arab. Setiap judul disertai contoh-contoh faktual dalam praktik pembelajaran bahasa Arab bagi penutur non-Arab.

\section{Pelatihan Peningkatan Kapasitas Pengajar Bahasa Arab}

Pelatihan tahap pertama merupakan pelatihan untuk peningkatan kapasitas pengajar dari ranah pedagogis dan keterampilan mengajar. Pelatihan pada tahap ini menekankan pada hasil identifikasi awal agar Tim PPM dapat memberikan wawasan strategi dan metode pengajaran bahasa Arab bagi para calon pengajar. Di antara metode pengajaran yang disampaikan oleh Dosen pelaksana PPM adalah metode gramatika-terjemah, metode audio lingual, metode membaca, metode komunikatif dan metode eklektik. Selain itu, dalam kesempatan ini disampaikan juga metode pengajaran bahasa yang diadopsi dari metode di ranah psikologi seperti silent way dan suggestopedia.

Selain metode-metode tersebut, para guru Pesantren juga menyampaikan materi seputar metode langsung. Meskipun secara praktis para sasaran program sudah sangat familiar dengan metode langsung, namun penyampaian materi secara teoretis tetap dipandang penting. Para guru Pesantren sebagai nara sumber dalam sesi ini membahas metode tersebut dengan segala kekurangan dan kelebihannya, syarat penggunaannya serta pengalaman mengajar para guru Pesantren selama menggunakan metode tersebut dalam mengajarkan bahasa Arab.

Pada pertemuan selanjutnya, Tim PPM menyampaikan strategi-strategi pengajaran 4 keterampilan berbahasa beserta unsur-unsurnya yang meliputi pengajaran fonetik, kosa kata dan tata bahasa. Strategi pengajaran ini mengacu pada garis besar modern pengajaran bahasa. Strategi ini juga dibahas satu persatu berdasarkan konsep setiap metode pengajaran yang telah disampaikan pada pertemuan sebelumnya. Selanjutnya Tim PPM menyampaikan gambaran faktual pengajaran bahasa Arab di Indonesia. Wawasan inilah yang belum banyak diketahui siswa dan siswi akhir sebagai calon pengajar. Sesi ini ditutup dengan dialog interaktif seputar dinamika pengajaran bahasa Arab di Indonesia dengan berbagai jenjang pengajarannya.

Beberapa catatan penting yang dihasilkan dari dialog interaktif ini adalah pemilihan metode pengajaran bahasa hendaknya selalu mengutamakan tujuan dari pengajaran bahasa yang telah dirumuskan dalam kurikulum, silabus bahkan visi dan misi lembaga pendidikan baik formal maupun non formal. Selanjutnya pemilihan metode perlu didasarkan pula pada latar belakang pembelajaran bahasa Arab siswa, alokasi waktu, media pendukung yang tersedia serta jumlah peserta dalam rombongan belajar. Catatan lain yang dihasilkan adalah adanya 2 metode pengajaran yang banyak digunakan dalam pengajaran bahasa Arab di Indonesia, yaitu metode gramatika terjemah yang digunakan untuk tujuan memahami teks-teks keagamaan dan metode langsung dan metode komunikatif yang digunakan untuk tujuan komunikatif.

\section{Program Arabic Camp sebagai Peningkatan Kete- rampilan Bahasa Arab}

Pelatihan tahap kedua dilaksanakan diinisiasi oleh Divisi Peningkatan Bahasa di Pesantren Darussalam. Arabic Camp merupakan program tahunan yang dilaksanakan di Pesantren ini, dan pada rentang masa program Pengabdian pada Masyarakat ini Tim PPM Universitas Padjadjaran menjadi narasumber dalam kegiatan ini. Tujuan utama kegiatan adalah meningkatkan keterampilan berbahasa Arab para santri di semua ranahnya: menyimak, berbicara, membaca, dan menulis.

Meskipun bertujuan untuk meningkatkan 4 keterampilan berbahasa, namun pelatihan ditekankan pada peningkatan keterampilan berbicara dengan fokus pembelajaran bahasa Arab komunikatif. Pelatihan dihadiri oleh 2 orang narasumber dari penutur asli Sudan yang memberikan contoh pelafalan kata dan kalimat bahasa Arab yang baik dan benar. Setelah itu Tim PPM juga menyampaikan pelatihan bahasa Arab komunikatif yang diambil dari modul yang telah disusun. Pada kesempatan tersebut, materi yang diajarkan adalah judul pertama yaitu Salam, Sapaan, dan Perkenalan. Narasumber dari penutur asli Sudan menyampaikan bahwa dalam penyampaiannya, ia akan meminimalisir penggunaan bahasa ibu sebagai bahasa pengantar agar santri terbiasa mendengar dan berbicara dengan bahasa Arab. Beliau juga menyarankan agar para guru melakukan hal yang sama saat pembelajaran bahasa Arab komunikatif. Di akhir acara, beberapa santri diminta untuk langsung mempraktikkan latihan-latihan berbicara seperti pelafalan, percakapan, diskusi, dan pidato dalam bahasa Arab.

Pelatihan ini juga bertujuan untuk membentuk kader pengajar bahasa Arab komunikatif. Secara garis besar, pelatihan ini berisi cara pengajaran bahasa Arab komunikatif dengan metode langsung dan metode komuunikatif. Pelatihan juga berisi cara penggunaan modul keterampilan berbicara bahasa Arab dengan menekankan karakteristik autonomous learning.

Secara garis besar, berikut tahapan-tahapan yang dilalui dalam program pengabdian ini: 
Tabel 1. Tahapan Kegiatan Pengabdian pada Masyarakat

\begin{tabular}{|c|c|c|c|c|}
\hline \multirow{2}{*}{ No } & \multirow{2}{*}{ Rencana Kegiatan } & \multicolumn{3}{|c|}{ Keterlibatan dalam kegiatan } \\
\hline & & $\begin{array}{c}\text { Dosen } \\
\end{array}$ & Mahasiswa & Masyarakat \\
\hline 1 & Seminar & $\begin{array}{l}\text { Menjadi narasumber dalam seminar } \\
\text { tentang peningkatan kompetensi } \\
\text { pengajar bahasa Arab }\end{array}$ & $\begin{array}{l}\text { Membantu dosen dan } \\
\text { masyarakat dalam acara } \\
\text { seminar. }\end{array}$ & $\begin{array}{l}\text { Mengikuti seminar dan } \\
\text { evaluasi }\end{array}$ \\
\hline 2. & Pembinaan & $\begin{array}{l}\text { Memberikan dan menginventarisir } \\
\text { saran-saran rekonstruksi materi } \\
\text { pada mata pelajaran at-tarbiyah wa } \\
\text { 'tta'lim }\end{array}$ & $\begin{array}{l}\text { Membantu menyusun data } \\
\text { dan membuat bahan tayang }\end{array}$ & Mengikuti pembinaan \\
\hline 3. & Pendampingan & $\begin{array}{l}\text { Menyiapkan bahan untuk } \\
\text { penyuluhan dan diskusi interaktif } \\
\text { bersama santri dan guru sebagai } \\
\text { fasilitator }\end{array}$ & $\begin{array}{l}\text { Menyiapkan kebutuhan } \\
\text { penyuluhan }\end{array}$ & $\begin{array}{l}\text { Mengikuti dan } \\
\text { berperan aktif dalam } \\
\text { pendampingan }\end{array}$ \\
\hline 4. & Kaji Tindak & $\begin{array}{l}\text { Menyusun karya pengabdian } \\
\text { "ta'zizu kafaati mu'allimil lughah } \\
\text { al-'arabiyyah li'n nathiqina } \\
\text { bighairiha” dan menyampaikan } \\
\text { isinya dalam pelatihan }\end{array}$ & $\begin{array}{l}\text { Membantu proses } \\
\text { pencetakan dan } \\
\text { penggandaan buku }\end{array}$ & $\begin{array}{l}\text { Guru membantu } \\
\text { mensosialisasikan buku } \\
\text { dan kerangka materi } \\
\text { pelatihan }\end{array}$ \\
\hline
\end{tabular}

Tabel 2. Indikator Keberhasilan Program

\begin{tabular}{|c|c|c|c|}
\hline No. & Indikator & $\begin{array}{c}\text { Base Line } \\
\text { (sebelum kegiatan) }\end{array}$ & $\begin{array}{c}\text { Pencapaian } \\
\text { Setelah Kegiatan }\end{array}$ \\
\hline 1. & $\begin{array}{l}\text { Wawasan santri calon pengajar tentang } \\
\text { dinamika pembelajaran bahasa Arab } \\
\text { di Indonesia }\end{array}$ & $\begin{array}{l}\text { Wawasan santri calon pengajar } \\
\text { terbatas pada metode langsung } \\
\text { dalam pengajaran bahasa Arab } \\
\text { bagi penutur non-Arab }\end{array}$ & $\begin{array}{l}\text { Santri calon pengajar memiliki } \\
\text { wawasan yang cukup memadai tentang } \\
\text { metode dan strategi pengajaran bahasa } \\
\text { Arab bagi penutur non Arab dan mampu } \\
\text { mengaplikasikannya dalam micro } \\
\text { teaching }\end{array}$ \\
\hline 2. & $\begin{array}{l}\text { Meningkatnya kapasitas santri calon } \\
\text { pengajar secara pedagogis }\end{array}$ & $\begin{array}{l}\text { Kompetensi } \text { santri } r \text { calon } \\
\text { pengajar dalam praktik mengajar } \\
\text { sudah cukup memadai, namun } \\
\text { pengetahuan pedagogis masih } \\
\text { kurang }\end{array}$ & $\begin{array}{l}\text { Kapasitas santri calon pengajar secara } \\
\text { teoritis dan praktis meningkat yang } \\
\text { dibuktikan saat praktik micro teaching }\end{array}$ \\
\hline 3. & $\begin{array}{l}\text { Memiliki perencanaan dalam mere- } \\
\text { konstruksi materi al tarbiyah wa al ta'lim } \\
\text { dengan muatan teori-teori pengajaran } \\
\text { bahasa Arab bagi penutur non Arab }\end{array}$ & $\begin{array}{l}\text { Belum ada perencanaan untuk } \\
\text { merekonstruksi materi }\end{array}$ & $\begin{array}{l}\text { Tersusunnya kerangka rekonstruksi } \\
\text { materi dasar untuk mengajar di } \\
\text { Pesantren Darussalam yaitu at tarbiyah } \\
\text { wa 'tta'lim yang dilengkapi dengan } \\
\text { muatan teori-teori pengajaran bahasa } \\
\text { Arab bagi penutur non Arab }\end{array}$ \\
\hline
\end{tabular}

\section{Kontribusi Program Bagi Khalayak Sasaran}

Program ini dilaksanakan oleh dosen PPM bekerjasama dengan aparat desa, Ketua Pesantren Darussalam Tasikmalaya, guru-guru Pesantren, dan 2 penutur asli dari Sudan. Kontribusi program ini bagi khalayak sasaran antara lain:

1. Memberikan pengetahuan tentang metode dan strategi pengajaran bahasa Arab sebagai bahasa asing.

2. Memberikan wawasan tentang dinamika pengajaran bahasa Arab di Indonesia, khususnya di lembagalembaga non-Pesantren

3. Memotivasi guru dan santri untuk menggunakan metode pengajaran bahasa Arab sesuai dengan tujuan pembelajaran bahasa.

4. Terjalin upaya bersama antara dosen, dan masyarakat untuk mencapai tujuan

5. Mahasiswa bersama dosen pembimbing dapat menerapkan ilmu yang telah diperoleh di bangku kuliah dan belajar bermasyarakat dengan baik.

Secara keseluruhan, program ini telah berhasil mencapai tujuannya dengan indikator keberhasilan yang disajikan dalam tabel berikut:

\section{SIMPILAN}

Fokus utama yang menjadi tujuan dalam kegiatan pengabdian ini adalah peningkatan kompetensi calon pengajar di PesantrenDarussalamdariranahpedagogis danketerampilan berbahasa Arab. Berdasarkan hasil pelaksanaan kegiatan selama 5 bulan, tim pelaksana dapat menyimpulkan bahwa metode yang digunakan dalam pengabdian ini sudah tepat dan efektif untuk mencapai tujuan yang telah ditetapkan di awal kegiatan. Dengan pendampingan dan kaji tindak yang diimplementasikan dalam bentuk pelatihan bagi calon pengajar di Pesantren Darussalam, sasaran program di akhir kegiatan memiliki wawasan yang cukup memadai tentang metode dan strategi pengajaran bahasa Arab bagi penutur non Arab dan mampu mengaplikasikannya dalam praktik mengajar (micro teaching). Hal tersebut merupakan indikator keberhasilan metode yang digunakan karena wawasan santri calon pengajar pada saat identifikasi awal hanya terbatas pada metode langsung dalam pengajaran bahasa Arab bagi penutur non-Arab.

Efektifitas dari metode penyuluhan yang digunakan oleh Tim Dosen Pelaksana juga tercapai dengan 
tersusunnya kerangka rekonstruksi materi dasar untuk mengajar di Pesantren Darussalam yaitu at tarbiyah wa 'tta'lim yang dilengkapi dengan muatan teori-teori pengajaran bahasa Arab bagi penutur non Arab.

\section{DAFTAR PUSTAKA}

Budiana, Nia. (2017). Keterampilan Berbicara: Desain Pembelajaran Berbasis Quantum Teaching. Malang: Universitas Brawijaya Media.
Sanjaya, Wina. (2015). Perencanaan dan Desain Sistem Pembelajaran. Jakarta: Penerbit Kencana.

Syihabuddin, Nadhif. (2014). Kajian Teoritis Pendekatan Komunikatif Dalam Pengajaran Bahasa Arab, Yogyakarta: Universitas Islam Negeri Sunan Kalijaga

Wekke, Ismail Suardi. (2015). Model Pembelajaran Bahasa Arab. Yogyakarta: Deepublish Publiser. 